\title{
Snake Gourd (Trichosanthes cucumerina L.): An Underutilized Crop with Great Potentials
}

\author{
D.O. Idowu ${ }^{1}$, A. B. Fashina ${ }^{2}$, O. E. Kolapo ${ }^{3}$, and O. M. Awolusi \\ ${ }^{1}$ Department of Agricultural Engineering Ladoke Akintola University of Technology \\ Ogbomoso, Oyo State, Nigeria \\ ${ }^{2}$ Department of Animal Nutrition and Biotechnology Ladoke, Akintola University of \\ technology Ogbomoso, Oyo State, Nigeria \\ *Corresponding author
}

\section{A B S T R A C T}

Keywords Snake gourd, origin, botanical characteristics, nutrition, cultivation, and economic value

Article Info

Accepted:

18 August 2019

Available Online:

10 September 2019
Snake gourd plant is a crop of great potentials. It is a crop that grows well in a tropical climate. The crop can be cultivated for personal consumption or for commercial purpose. The esfruit is highly nutritious and good source of vitamins. It has been proofed that it improves appetite and used in the treatments of disease like fever, head ache, alopecia, skin rachises etc. For the potential of this crop to be harness, more research should be encouraged on its mechanization and utilization which will eventually promote its commercialization. This paper therefore describes the origin, distribution, botanical characteristics, cultivation, nutrition, economic values and the need of exploring the nutritional and economic potential of snake gourd.

\section{Introduction}

It has been reported that western and central African sub region have several underutilized crops that are very useful to the local people (FAO, 1998; Abukutsa- Onyago, 2003).

The world health organization has reported a high presence of malnutrition level among the rural duelers in Africa. Jildeh et al., 2010 reported high deficiency in protein for over 100 million people in Africa. Researchers has reported importance of some indigenous but neglected edible plants in nutrition of the rural populations in Africa (Adebooye et al., 2001, Abutkutsa-onyago, 2003).

One of these plant is Snake gourd plant that has been reported as source of high nutrient plant which could serve as a supplement for rural dwellers that cannot afford milk and other expensive nutritional product.

The seed has been reported to have high quality of vegetable oil which could be used as food and other industrial purposes. 


\section{Origin and Distribution of Snake gourd}

Snake gourd (Trichosanthes cucumerina L.) is generally believed to have originates from India (Echo, 2006). It originated in a wild state, but later domesticated. The wild specie could still be found in India and other part of South East Asia, Australia, West Africa, Latin America and the Caribbean (Echo, 2006). Snake gourd has 70 genera and over 700 species. The snake gourd (Fig. 1) is known by different names in different part of the World. In Nigeria it is known as snake tomato, pathakaya in India, pakupis in Philippines, baup ngu in Thailand, pudalankaai in Tamil, paduvalakaayi in Kannada and padavalanga in Malayam (Echo, 2006).

\section{Botanical Characteristics of Snake gourd}

The snake gourd belongs to the family cucurbitacea. The crop is a climber that can grow to 5 metres (Brickell, 1990). It climbs by means of tendrils. The Snake gourd has slightly twining stem (Grey-Wilsonand Mathews, 1983). It is commonly called snake gourd, viper gourd, snake tomato or long tomato (Ojiako and Igwe, 2008). Onagoruwa (2002) noted that there are two types of snake gourd in Nigeria. Both types have long fruits but they differ in colour. One is of deep green while the other is of light green. The flowers of snake gourd are mondecious, but both female and male flowers can be found on the same plant. These flowers are white, aromatic and always open late in the day.

\section{Cultivation of Snake Gourd}

Snake gourd can be grown twice in a year in a tropical climate like Nigeria. The first cultivation is between April to July, while the second is August to November (Oloyede and Adebooye, 2005). Irrigation may be needed in climates with seasonal droughts. The crop can thrive on sandy, sandy loam and light clay soils (Huxley, 1992).

However, the soils should be well drained. The average growth temperature is $30-34{ }^{\circ} \mathrm{C}$ (Echo, 2006).

Oloyede and Adebooye (2005) noted that plant spacing of one metre between rows and one metre within rows is adequate for snake gourd.

Seeds should be planted two per hole and three weeding during the life of the crop are recommended. Avoidances of high dosage of nitrogenous fertilizer should be observed. It was observed that excess nitrogen in the soil would produce crop with excess vines and less fruits.

Snake gourd takes about 16 weeks from planting to maturity (Hedrick, 1972; Huxley, 1992). During growth the crops vines and long fruits can be supported by bamboo trellis of about $1.5 \mathrm{~m}$ high or a small trellis of concrete reinforcement wire of $100 \mathrm{~cm}^{2}$ meshes.

The vines may also be allowed to either grow up poles. Over hatched rooftops or over walls.

\section{Harvesting and Post-Harvest Handling of Snake Gourd}

Harvesting and post-harvest handling of snake gourd are done manually. The matured fruits are ready for harvesting 12-20 days after fruit set. The fruit turns yellow if not harvested immediately (Figure 2).

In countries like Nigeria where matured fruits are used as soup additive the fruits are harvested when they begin to change from green to orange or red colour. Snake gourds do not keep well after harvest. However, they can be stored for 10- 14 days at a temperature of $16-17^{\circ} \mathrm{C}$ and a relative humidity of $85-90 \%$. 
Fig.1 Snake gourd fruit

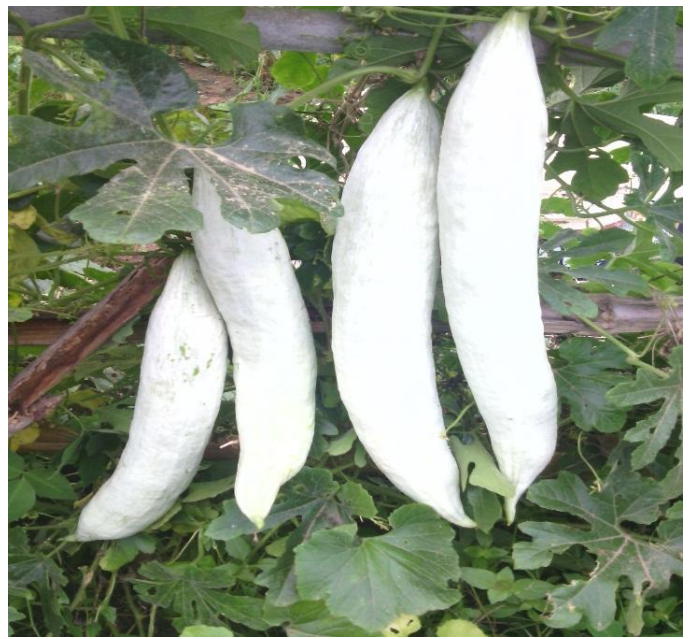

Source: LAUTECH Agricultural Engineering Farm

Fig.2 A fully matured ripe snake gourd fruit

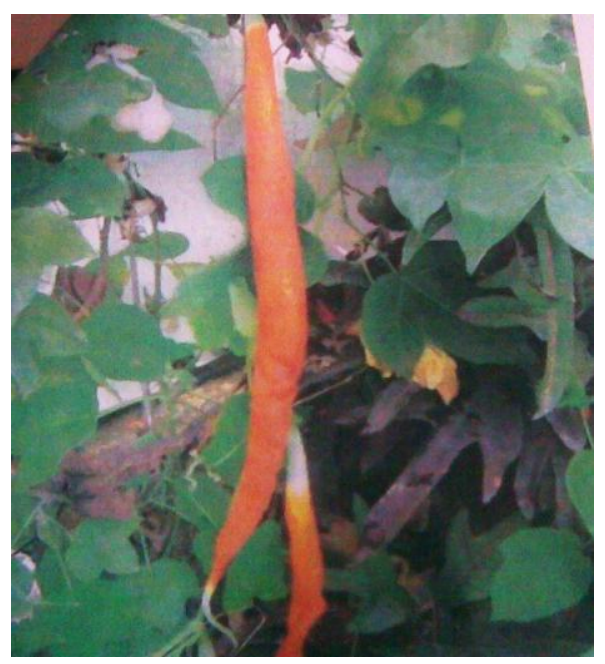

Fig.3 Snake Gourd Seed

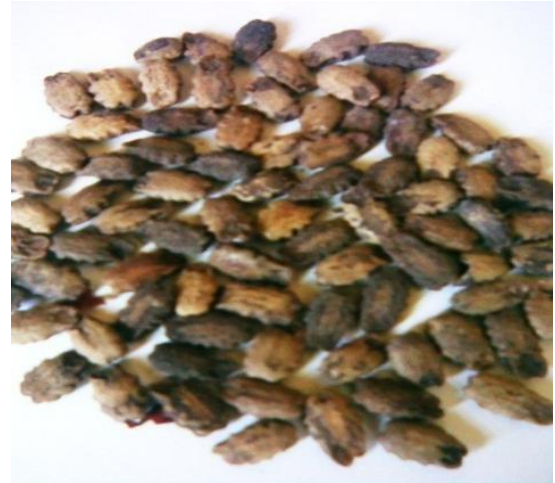


Table.1 Nutritional Facts of Snake Gourd Fruit

\begin{tabular}{|c|l|c|}
\hline $\mathrm{S} / \mathrm{N}$ & Food Property & Composition \\
\hline 1 & Calories & 86.2 \\
\hline 2 & Total Fat & $3.9 \mathrm{~g}$ \\
\hline 4 & Saturated Fat & $0.5 \mathrm{~g}$ \\
\hline 5 & Polyunsaturated Fat & $1.6 \mathrm{~g}$ \\
\hline 6 & Monounsaturated Fat & $1.6 \mathrm{~g}$ \\
\hline 7 & Total Carbohydrate & $12.5 \mathrm{~g}$ \\
\hline 8 & Dietary Fiber & $0.6 \mathrm{~g}$ \\
\hline 9 & Sugars & $0.6 \mathrm{~g}$ \\
\hline 10. & Pantothenic Acid & $3.0 \%$ \\
\hline 11. & Vitamin $\mathrm{B}_{12}$ & $0.0 \%$ \\
\hline 12. & Vitamin $\mathrm{B}_{6}$ & $11.3 \%$ \\
\hline 13. & Vitamin $\mathrm{C}$ & $30.5 \%$ \\
\hline 14. & Vitamin D & $0.0 \%$ \\
\hline 15 & Vitamin E & $1.1 \%$ \\
\hline 16. & Calcium & $5.1 \%$ \\
\hline 17. & Copper & $4.4 \%$ \\
\hline 18. & Folate & $5.6 \%$ \\
\hline 19. & Riboflavin & $2.7 \%$ \\
\hline 20. & Selecnium & $3.1 \%$ \\
\hline 21, & Thiamin & $5.2 \%$ \\
\hline 22 & Sodium & $33.0 \mathrm{mg}$ \\
\hline & Source: DrHeathBent \\
\hline
\end{tabular}

Source: DrHealthBenefits.com

Table.2 Nutrient Composition of T.cucumerina Seeds

\begin{tabular}{ll}
\hline Nutrients & Composition \\
\hline Crude protein & $26.2-26.6 \mathrm{~g} / 100 \mathrm{~g}$ \\
Fat & $44.6-57.2 \mathrm{~g} / 100 \mathrm{~g}$ \\
Phosphorus & $78.0-81.5 \mathrm{mg} / 100 \mathrm{~g}$ \\
Calcium & $41.0-46.7 \mathrm{mg} / 100 \mathrm{~g}$ \\
\hline
\end{tabular}

Source: Oloyede and Adebooye (2005)

Table.3 Major vegetable oilseeds, their average oil content and estimated World production for the year 1995- 1999 (Anonymous 1995)

\begin{tabular}{llc}
\hline $\begin{array}{l}\text { Oilseed } \\
\text { and fruit (million metric tonnes) }\end{array}$ & Oil content $(\%)$ & Oil production \\
\hline Soybean & 21 & 19.3 \\
Cottonseed & $23 / 33^{*}$ & 3.59 \\
Rapeseed & 42 & 9.8 \\
Peanut & 42 & 3.97 \\
Sunflower & 44 & 7.77 \\
Coconut/copra & 65 & 3.08 \\
Palm kernel & $33 / 45^{*}$ & 1.98 \\
Palm & $37 / 66^{* *}$ & 14.2 \\
Olive & 30 & 1.67 \\
\hline
\end{tabular}

$*$ dehulled ** dry basis 


\section{Uses of Snake Gourd}

The snake gourd fruit comprises essentially the pulp and the seed. Unlike most oil producing crops, both the pulp and the seed are narratively useful. The pulp is used as a substitute in soup to solanaceous tomato because of its sweet taste, aroma and deep red endocarp colour when fully ripe (Adebooye $e t$ al., 2007; Deepa, 2017). The presence of high ascorbic acid which is higher than that of popular solanaceous tomato varieties suggest the possibility of utilizing snake gourd in the industrial production of tomato paste and puree. The seeds when dried is used in alternate medicine for treating anthelmintic and diarrhea. It has been reported that the seed contain anti-bacterial (Yusuf et al., 2007) which may make it a potential insecticide. The proximate composition of the fruit (Table 1) while Table 2 present the reported proximate composition of the seed.

The seed (Figure 3) is a good source of edible oil. Many researcher have observed that the presence of antioxidant, such as, carotenoids, flavoriods, lycopene, phenolics and $\beta$-carotene in the oil, helps in protection against diseases like cardiovascular, diabetes, and so on (Velioghu et al., 1998; Loheu et al., 2000; Liu et al., 2000; Knakt, 2002, Sweeney et al., 2002; Amin et al., 2004; Sahin et al.,2004; Zharg and Hemauzy, 2004). Perhaps the most interesting news is that the AIDS drug Compound $\mathrm{Q}$ is a refined protein called trichonanthine which is derived from the trichosanthes (snake gourd) family. It has been shown that the protein has the ability to kill an HIV infected cell without affecting surrounding tissue.

The snake gourd seed oil contains 26.2-26.6\% crude protein, $44.6-57.7 \%$ fat, $7.8-8.15 \%$ phosphorus and $0.012-0.026 \%$ anti-nutritional oxalate (Adebooye, et al., 2005). Idowu 2015 reported $45 \%$ oil content for the seed. The oil content of the seed compared favorably with that of most seed oil (Table 2). They noted that this anti-nutritional oxalate is low and safe for humans. Skumarlabot (2007) notes that other parts of snake gourd, such as, shoots, tendrils and leaves are eaten as vegetables. However, it was recommended that these parts should be boiled before eaten to remove some unpleasant odours (Echo, 2006). It has been reported that the plant contains some pharmacological impotance like antidiabetic, hepatoprotective, hepatoprotective, cytotoxic anti-inflammatory, larvicidial effect (Kritikar and Basu 2006; Sathesh et al., 2009).

Generally the plant was believe to be of high value because of the presence of carotenoidds, flavonoids, lycopene, phenolics and Bcarotene (Anuradha and Bhide, 1999: Khare, 2007: Swamy et al., 1998: Yadava and Syeda 1994 ;Yusuf et al., 2007).

\section{Challenges to Agricultural Engineers and other Agriculturist}

The ability of a particular oil seed to fit into the growing industries depends on its utilization potential, rate of production and availability of the processing technology. It had been proofed that the utilization potential of snake gourd is high but its production and processing technologies are low. Although, Idowu and Owolarafe (2014) has reported effect of moisture content on the seed engineering properties; Idowu and Owolarafe (2013) on the aerodynamic properties of the seed; Idowu (2015) on the effect of seed washing on the snake gourd oil yet a lot is still needed to be done to encourage production. The agricultural engineers should work with the soil scientist, agronomist and breeders to evolve production technologies of high yielding varieties of snake gourd. Also, agricultural engineers should work with other food scientist to develop machinery and 
processing procedure to produce essential products from snake gourd.

The economic potentials of snake gourd were very high but its production and processing technologies are low. The present global food crises call for an urgent coordinated research in some useful but neglected crops, in which snake gourd is one. The successful outcome of these research works can create job, increase foreign exchange of the country or countries involved, increase food production and possibility improve the health of the people.

\section{References}

Adebooye, O.C., Oloyede, F.M. Opabode, J.T., and Onagoruwa, O.O. (2007). Fruit Characteristics and Nutrient Composition of Landrace Mophotypes of Snake Gourds. Journal of Vegetable Science, 6(4): 6-7.

Abukusa-Onyago, M.A. (2003). The role of African indigenous vegetable in poverty alleviation in Kenya. Proceeding of the $1^{\text {st }}$ PROTA International Workshop 23-25, September, 2002. Nairobi, Kenya 269-270.

Anuradha P., Bhide, S.V., 1999. An isolectin complex from Trichosanthes anguina seeds. Phytochemistry. 52 (5):751758.

Amin, I., Zamaliah, M.M., and Chin W. F. (2004): Tropical Plant Database. Trichosanthes kirilowii.Journal of Food Chemistry, 87: 581-586.

Brickell, C. (1990). The RHS Gardens Encyclopedia of plants and Flowers. Dorling Kindersley Publisher Ltd.

Devi D.N. 2017. Medicinal values of Trichosanthus cucumerina L(Snake Gourd). British Journal of Pharmaceutical Research 16 (1)1-10

DrHealthBenefits.Com: 33 Snake gourd Health Benefits you must know. accessed in $9^{\text {th }} \quad$ November 2016 ECHO (2006). Snake Gourd. www.echonet.org.

FAO (1998). In the global plan of action on plant genetic resources for food and agriculture. Rome, Italy. Pg 104.

Grey-Wilson and Mathew, V. (1983). Gardening on walls. ISBN-002192206.

Hedric, V.P. (1972). Sturtevants Edible plants of the World. DOV publication ISBN 0-486- 20459-6.

Huxley. A. (1992). The New RHS Dictionary of Gardening press. ISBN 0-33547494-5.

Idowu, D.O. and Owolarafe, O.K. (2013): A Study of Hydro-Aerodynamic Properties of Snake Gourd (Trichosanthes cucumerinas L.) Seed, Kernel and Chaff. Journal of Agricultural Technology. 9(7): 16911701.

Idowu D.O. and Owolarafe, O.K. (2014). Physical Properties of Snake Gourd Seed (Trichosantes cucumerina L) Relevant in Grading and Separation. Agric. Eng. Int:

CIGR Ejournal, 16 (1): 303-312.

Idowu D.O (2015). A study on the Effect of Washing of Kernel on Yield, Colour and a Rheological Property of Snake Gourd Oil. Journal of Agricultural Technology. 11(4): 811-822.

Jildeh, C, Papandreou C, Abu Mourad, T. (2010). Assessing the Nutritional Status of Palestinian Adolescents from East Jerusalem: A school-based study, 2002-2003. Journal of Tropical Pediatric, 31:89-94.

Khare, C.P. 2007. Indian medicinal plants and illustrated Dictoinary. Springer Science Publishers, New Deihi 7671-672.

Knekt. P., Kumpulainen. J., Jarvinen, R., Rissanen, H., Helioraara. M., 
Reunanen, A., Halulinen, T., Aromaa, A. (2000). Flavonoids Intake and Risk of Chronic Diseases. American

Journal of Clinical Nutrition, 76, 560568.

Kritikar K.R. and Basu B.D. 2006. Indian medicinal plant. International book distributors, New Deihi 2: 11121114

Ojiako, O.A. and Igwe, C.U. 2008. The nutritive, anti-nutritive and hepatotoxic properties of Trichosanthes anguina (snake Tomato) Fruit from Nigeria. Pakistan Journal of Nutrition. 7(1):85-89

Oloyede, F.M. and Adebooye, O.C., (2005). Effect of Season on Growth, Fruit Yield and Nutrient Profile of Two Landraces of Trichosanthes cucumerina L. African Journal of Biotechnology. 4(10): 1040-1044.

Onagoruwa, O.O. (2002). Diversity and Nutrient Composition of Trichosanthes cucumerina. L. Unpublished B.Sc. report submitted to Department of Agronomy, Obafemi Awoliowo University, Ile-Ife, Nigeria.

Sahlin. E., Savage. G.P., and Lister G.E., (2004). Investigation of the Antioxidant Properties of Tomatoes after Processing. Journal of Food Composition and Analysis. 17:635647.

Sathesh K.S., Ravi, K.B. Krishna M.G. 2009. Hepatoprotectives effect of
Tricosanthes cucumerinal $\mathrm{L}$ on carbon tetra chloride induced liver damage in rats.Journal of Ethnopharmacol. 123(2):347-350

Skumarlahot, L (2007). Trichosanthes cucumerina L. Wikipedia, the free encyclopedia.

Swamy, M.J., Komath, S.S., Nadimpalli, S.K. 1998. Identification of histidine resdues in the sugar binding site of snake gourd (Trichosanthes anguina) seed lectin. Biochem Moi Bio lint. 44(1); 107-116

Velioghu, Y.S., Mazza, G., Gao, L. and Oomah, B.D. (1998). Antioxidant Activity and Total Phenolics in Selected Fruits, Vegetables and Grain Products. Journal Agricultural Food Chemistry, 46: 4113-4117.

Yadava R.N, Syeda, Y. 1994An isoflavone glycoside from the seeds of Trichosanthes anguina. Phytochemistry, 36 (6); 1519-1521.

Yusuf A.A., Folarin O.M, Bamiro F.O. 2007. Chemical composition and functional properties of snake gourd (Tricosanthes cucumerina) seed flour. Nigerian Food Journal. 25 (1): 36-45.

Zharg, D. and Hamauzu Y., (2004). Phenollias, Ascorbic Acid, Carotenoids and Antioxidant Activity of Broccoli and their Changes during Conventional and Microwave Cooking. Food Chemistry Journal. 88:503-509

\section{How to cite this article:}

Idowu, D. O, A. B. Fashina, O. E. Kolapo and Awolusi, O. M. 2019. Snake Gourd (Trichosanthes cucumerina L.): An Underutilized Crop with Great Potentials. Int.J.Curr.Microbiol.App.Sci. 8(09): 1711-1717. doi: https://doi.org/10.20546/ijcmas.2019.809.194 